\title{
Penyelesaian Kredit Macet Logam Mulia Di PT. Pegadaian Sorong
}

\author{
H. Muhammad Ali ${ }^{1}$ \\ Imelda Pastiana Suaiba ${ }^{2}$ \\ Fakultas Hukum, Universitas Muhammadiyah Sorong \\ Email : Mulisidiq@yahoo.co.id ${ }^{1}$ \\ Email: f.hukums@gmail.com²
}

\begin{abstract}
Abstrak
Hasil penelitian menunjukan bahwa pertama, Upaya dalam penyelesaiaan kredit macet dalam pelaksanaan pembiayaan Logam MULIA dengan akad murabahah adalah dengan dua cara yaitu, Lelang Logam Mulia dan Musyawarah dengan Penawaran perpindahan status kredit yaitu Krasida, KCA dan Buyback. Kedua, Hambatan-Hambatan yang yang terjadi dalam proses penyelesaian kredit macet yaitu Hambatan dari nasabah dan Pegadaian, Hambatan Sarana Pendukung dan Hambatan Masyarakat. Melalui penelitian ini, penulis menyarankan kepada PT. Pegadaian Cabang Sorong agar lebih banyak lagi melakukan sosialisasi atau edukasi terhadap masyarakat tentang Logam Mulia Emas Batangan, karena banyak keuntungan yang didapatkan dari berinvestasi emas. Dan PT. Pegadaian cabang Sorong dalam meminimalisir hambatanhambatan yang sering terjadi, harus selalu mengupgrape system dan data nasabah dan pihak nasabah harus juga memberitahukan kepada PT. Pegadaian Cabang Sorong jika ada perubahan data.
\end{abstract}

Kata Kunci : Hukum Perdata, Hukum Islam, Penyelesaian Kredit Macet

\section{PENDAHULUAN}

Dalam usaha pertumbuhan perekonomiaan nasional pada saat ini. Perbankan merupakan lembaga keuangan yang sangat penting dalam menunjang keseluruhan program pembiayaan pembangunan, baik sebagai penghimpun dana, sebagai pembiayan investasi, maupun sebagai lembaga menyalurkan dana ke masyarakat luas. Dengan tujuan dapat memberikan kontribusi terhadap ekonomi masyarakat.

Selain lembaga keuangan bank, ada juga lembaga keuangan lainnya. Yang memberikan kontribusi terhadap ekonomi masyarakat. Salah satu lembaga keuangan lainnya yang telah lama dikenal masyarakat adalah PT. Pegadaian Cabang Sorong. Pada masa krisis PT. Pegadaian Cabang Sorong mendapatkan peluang untuk semakin berperan dalam pembiayaan, khususnya usaha kecil. Peran pembiayaan dalam pembiayaan masyarakat sesuai dengan tujuan PT. Pegadaian Cabang Sorong, di samping memupuk keuntungan. Selain itu juga sebagai penunjang kebijakan dan program pemerintah di bidang ekonomi dan pembangunan nasional melalui penyaluran pinjaman berdasarkan hukum gadai.

Pegadaian sampai saat ini merupakan satu-satunya lembaga formal di Indonesia yang berdasarkan hukum di perbankan melakukan pembiayaan denganbentuk penyaluran kredit atas 
dasar hukum gadai. Tugas pokok Pegadaian adalah menjembatani kebutuhan dana masyarakat dengan pemberian uang pinjaman berdasarkan hukum gadai. Tugas tersebut dimaksudkan untuk membantu masyarakat agar tidak terjerat dalam praktek-praktek lintah darat. Sesuai dengan moto"Mengatasi Masalah Tanpa Masalah "Pegadaian menawarkan sejumlah alternative pembiayaan sesuai dengan kebutuhan dana kebutuhan masyarakat. Namun seiring perkembangan zaman Pegadaian Syariah tidak hanya menawarkan produk dalam bentuk pembiayaan, tetapi juga menawarkan produk jual beli secara kredit.

Islam sebagai agama merupakan jalan hidup dan mempunyai nilai kesempurnaan yang tinggi, mengatur tata kehidupan manusia dalam mencapai taraf hidup yang layak, bahagia dan sejahtera. Kebahagiaan dan kesejahteraan itu akan terwujud jika manusia yang satu dengan manusia yang lainnya mampu mengadakan kerjasama untuk memenuhi hajat hidup antara sesamanya.

Kerjasama dalam bermuamalah sebagai bagian interaksi manusia dalam kerjasama antara dua orang atau lebih dalam berusaha, yang keuntungan dan kerugiannya ditanggung bersama. Muamalah adalah hukum-hukum yang berkaitan dengan tindakan manusia dalam persoalan keduniaan, misalnya dalam persoalan jual-beli, utang piutang, kerja sama dagang, perserikatan, kerja sama dalam penggarapan tanah, dan sewa-menyewa.

Jual beli adalah suatu perjanjian tukar menukar benda atau barang yang mempunyai nilai secara suka rela di antara kedua belah pihak, yang satu menerima benda-benda dan pihak lain menerima sesuai dengan perjanjian atau ketentuan yang telah dibenarkan syariat dan disepakati. Adapun pengertiannya secara syarieeah adalah saling menukar harta dengan harta dalam bentuk pemindahan milik dan pemilikan.

Berdasarkan ayat diatas bahwa manusia dilarang memperoleh harta dengan jalan batil (tidak benar) yang akan merugikan orang lain. Islam mengajarkan kepada umatnya agar di dalam memperoleh hartad engan jalan yang baik dan benar serta tidak merugikan orang lain. Setiap umat Islam boleh mencari nafkah dengan cara jual beli, tetapi cara harus dilakukan sesuai dengan syariat Islam, tidak boleh merugikan orang lain, tidak saling menipu orang lain, kepentingan umum dan bebas memilih sehingga tidak ada unsur memaksa.

Pada dasarnya jual beli adalah memindahkan barang dari tangan penjual ke tangan pembeli barang yang dapat dimanfaatkan oleh si pembeli didasarkan atas saling rela. Jual beli sendiri ada dua macam yaitu jual beli secara tunai dan jual beli secara tidak tunai yang biasa disebut kredit. 
Jual beli secara kredit ialah jual beli yang dilakukan dengan penyerahan barang di awal dan pembayarannya dilakukan secara berangsur atau dicicil dengan tempo waktu yang telah ditentukan oleh kedua belah pihak baik penjual maupun pembeli; (1) Bagaimana Penyelesaian Kredit Macet Logam Mulia di PT. Pegadaian Cabang Sorong ditinjau dari Hukum Islam?; (2) Apa saja kendala dalam Penyelesaian Kredit Macet Logam Mulia di PT. Pegadaian Cabang Sorong?

\section{PEMBAHASAN}

Kredit Istilah kredit berasal dari bahasa yunani (credere) yang berarti kepercayaan. Atau dalam bahasa latin "creditum" yang berarti kepercayaan atau kebenaran, atau credo, yang berarti $I$ believe, I trust. Saya percaya atau saya menaruh kepercayaan. Maksud dari percaya bagi si pemberi kredit adalah ia percaya kepada si penerima kredit bahwa kredit yang disalurkan pasti akan dikembalikan sesuai perjanjian. Sedangkan bagi si penerima kredit merupakan penerimaan kepercayaan sehingga mempunyai kewajiban untuk membayar sesuai jangka waktu.

Kredit menurut istilah adalah hak untuk menerima pembayaran atau kewajiban untuk melakukan pembayaran pada waktu yang diminta, atau pada waktu yang akan datang, karena penyerahan barang-barang sekarang. Sedangkan dalam syariah kredit dikenal dengan pembiayaan yaitu menyediakan uang atau tagihan berdasarkan persetujuan atau kesepakatan antara perusahaan dengan pihak lain, yang mewajibkan pihak lain mengembalikan pembiayaan tersebut setelah jangka waktu tertentu dengan imbalan bagi hasil.

Dalam bukunnya Sahruwardi K Lubis berpendapat bahwa yang dimaksud dengan kredit adalah suatu pembelian yang dilakukan terhadap sesuatu barang yang pembayaran harga barang tersebut dilakukan secara berangsur-angsur sesuai dengan tahapan pembayaran yang telah disepakati kedua belah pihak yaitu antara penjual ataupun pembeli.

Al-amien Ahmed mendefinisikan bahwa yang dimaksud dengan jual beli kredit (bai"attaqhsith) adalah menjual sesuatu dengan pembayaran yang diangsur dengan cicilan tertentu, pada waktu tertentu, dan lebih mahal dari pada pembayaran kontan.

Adapun menurut Undang-Undang Nomor 14 tahun 1967 tentang pokok-pokok Perbankan, yang dimaksud dengan kredit adalah penyediaan uang atau tagihan-tagihan yang dapat disamakan dengan itu berdasarkan persetujuan pinjam-meminjam antara bank dengan pihak lain dalam hal mana pihak peminjam berkewajiban melunasi utangnya setelah jangka waktu tertentu dengan jumlah bunga yang telah ditetapkan. 
Logam Mulia Emas batangan atau lebih dikenal Mulia merupakan bentuk investasi emas yang paling ideal meski membutuhkan modal awal yang lebih besar ketimbang lebih memilih perhiasan atau koin. Karena kandungan nilainya tertinggi dan tidak mengenal penyusutan nilai. Mulia adalah produk yang dibuat oleh produsen ternama dengan bentuk yang menyerupai batu bata. Di atasnya biasanya tercetak juga nama pembuat, berat, maupun kadar kemurnian dari emas tersebut. Berat emas batangan diukur dalam satuan karat. Biasanya emas batangan yang dijual berukuran 995 atau 999-995 berarti 995/ 1.000 atau kemurnian 99,5\% .

Emas batangan tersedia dalam berbagai bentuk dan ukuran. Emas batangan bisa dibeli dari satuan terkecil (biasanya 1 gram), 50 gram, 100 gram, hingga $1 \mathrm{~kg}$ atau 400 ons (biasanya untuk keperluan komersial). Makin besar ukuran emas batangan biasanya jatuhnya akan lebih murah karena biaya pembuatan dan premiumnya lebih kecil.

Di dunia ini hanya ada 55 produsen yang berhak memproduksi emas batangan 400 ons yang dikenal dengan istilah "London Good Delivery". Emas batangan ukuran ini biasanya digunakan oleh bank yang menyimpan cadangan emas. Diperkirakan sekitar 2,5 juta emas batangan ukuran tersebut di dunia ini dengan produksi tahunan 150.000 batang.

Ada pula ukuran kilobar atau 1.000 kilo yang biasanya digunakan untuk keperluan trading dan investasi. Karena ukurannya begitu besar, maka premium yang dikenakan jauh lebih murah. Biasanya emas jenis ini digunakan oleh bank dan institusi keuangan.Kebanyakan emas ukuran kilobar bentuknya datar (flat), walaupun investor di Eropa lebih banyak menyukai emas kilobar dengan lekukan seperti batu bata (brick). Orang-orang Eropa lebih menyukai emas dalam bentuk 10 ons dan 100 ons karena dianggap lebih praktis dan likuid. Sementara di Asia, terutama Jepang bentuk yang disukai adalah kilo gold bar (32,15 ons).

Emas batangan berukuran kecil sering disebut juga gold wafer atau goldbiscuit. Terkadang ada pula yang menyebutnya dengan istilah nugget. Emas batangan berukuran kecil tersebut (10 ons atau kurang) diperuntukkan bagi investor individu. Untuk yang pertama kali memegang emas batangan, mungkin akan terkejut karena emas batangan 100 ons akan terasa begitu berat dibandingkan benda dengan benda dengan massa yang serupa ukurannya.

Jual Beli Kredit Menurut Hukum Islam Dalam bahasa Arab jual beli dikenal dengan istilah alBai. Menurut istilah (terminologi) yang dimaksudkan dengan jual beli adalah yaitu suatu perjanjian tukar-menukar benda atau barang yang mempunyai nilai secara sukarela di antara kedua belah 
pihak, yang satu menerima benda-benda dan pihak lain menerimanya, sesuai dengan pernjanjian atau ketentuan yang telah dibenarkan Syara' dan disepakati.

Sebagian Fuqaha berpendapat bahwa arti "jual" adalah memindahkan kepemilikan harta dengan harta (tamlik al-mal bi al-mal). Sebagian lagi mengartikan bahwa "jual" secara bahasa adalah mengeluarkan zat dari pemilikan dengan suatu ganti. Sedangkan arti "beli" adalah memasukkan zat kedalam milik dengan ada ganti, atau pemilikan harta dengan harta.

Jual beli menurut bahasa ialah saling menukar (pertukaran), sedangkan menurut syara"e jual beli adalah pertukaran harta atas dasar saling sukarela (,antaradhin), atau memindahkan hak kepemilikan harta terhadap suatu benda atau harga dengan ganti yang dapat dibenarkan oleh hukum yaitu berupa alat ukur (acuan) yang sah.

Jual beli adalah suatu perjanjian, dengan mana pihak yang satu mengikatkan dirinya untuk menyerahkan suatu kebendaan, dan pihak yang lain untuk membayar harga yang telah dijanjikan. Secara global terdapat dua pendapat ulama tentang jual emas dengan uang kertas secara angsuran:

Pendapat pertama: haram: ini adalah pendapat mayoritas ulama, denganargumen (istidlal) berbeda-beda. Argumen paling menonjol dalam pendapat ini adalah bahwa uang kertas dan emas merupakan tsaman (harga, uang): sedangkan tsaman tidak boleh diperjualbelikan kecuali secara tunai. Hal ini berdasarkanhadist „Ubadah bin al-Shamit bahwa Nabi saw bersabda, Jika jenis (harta ribawi)ini berbeda, maka jualbelikanlah sesuai kehendakmu apabila dilakukan secara tunai.

Pendapat kedua: boleh (jual beli emas dengan angsuran). Pendapat ini didukung oleh sejumlah fuqaha masa kini: di antara yang paling menonjol adalah Syekh Abdurrahman As-Sa"di. Meskipun mereka berbeda dalam memberikan argumen (istidhlal) bagi pandangan tersebut, hanya saja argumen yang menjadi landasan utama mereka adalah pendapat yang dikemukakan oleh Syeikh al-Islami Ibnu Taymiyah dan Ibnu Qayyim mengenai kebolehan jual beli perhiasan (terbuat emas) dengan emas, dengan pembayaran tangguh. Mengenai hal ini Ibnu Taymiyyah menyatakan dalam kitab al-Ikhtiyarat (lihat „Alaee al-Din Abu al-Hasan al-Ba"liy al-Dimasyqiy, al-Ikhtiyarat alFiqhiyah min Fatawa Syaikh IbnTaimiyah, al-Qahirah, Dar al-Istiqomah, 2005, h. 146)

"Boleh melakukan jual beli perhiasan dari emas dan perak denganjenisnya tanpa syarat harus sama kadarnya (tamatsul), dan kelebihannya dijadikan sebagai kompensasi atas jasa pembuatan perhiasan, baik jual beli itu dengan pembayaran tunai maupun dengan pembayaran tangguh, selama perhiasan tersebut tidak dimaksudkan sebagai harga (uang).

Ibnu Qayyim menjelaskan lebih lanjut: "Perhiasan (dari emas atau perak)yang diperbolehkan, karena pembuatan (menjadi perhiasan) yang diperbolehkan, berubah statusnya menjadi jenis 
pakaian dan barang, bukan merupakan jenis harga (uang). Oleh karena itu, tidak wajib zakat atas perhiasan (yang terbuat dari emas atau perak) tersebut, dan tidak berlaku pula riba (dalam pertukaran atau jual beli), sebagaimana tidak berlaku riba (dalam pertukaran atau jual beli) antara harga (uang) dengan barang lainnya, meskipun bukan dari jenis yang sama. Hal itu karena dengan pembuatan (menjadi perhiasan) ini, perhiasan (dari emas) tersebut telah keluar dari tujuan sebagai harga (tidak lagi menjadi uang) dan bahkan telah dimaksudkan untuk perniagaan. Oleh karena itu, tidak ada larangan untuk memperjual belikan perhiasan emas dengan jenis yang sama.

Prosedur Kredit Logam Mulia Dalam penjualan kredit logam mulia/emas, ada beberapa metode penjualan, pembeli dapat melakukan secara online atau datang langsung ke PT. Pegadaian Cabang Sorong. Prosedur untuk penjualan kredit Mulia sebagai berikut; (A) Tahap Permohonan Kredit, Dalam Pembelian secara kredit nasabah dapat melakukannya secara online dengan mengunjungi website pegadaian di www.pegadaian.co.id, namun untuk pembayaran dalam pembelian secara online, PT Pegadaian belum terdapat sistem transfer sehingga nasabah harus tetap mengunjungi Kantor Cabang PT. Pegadaian terdekat. Selain itu Pembelian kredit juga dapat mengunjungi langsung PT. Pegadaian, nasabah harus memenuhi persyaratan berikut; (1) Memberikan fotokopi identitas diri seperti TP/SIM/Paspor; (2) Mengisi data formulir yang telah disediakan oleh pengelola PT. Pegadaian Cabang Sorong, yang didalamnya berisikan; (a) Identitas Pemohon; (b) Identitas Usaha/Profesi; (c) Data Pekerjaan Lainnya; (d) Data Suami/Istri/Saudara yang bisa dihubungi; (e) Penghasilan dari Usaha Tetap dan Usaha Lainnya; (f) Tujuan Atau Niat Pembelian; (g) Rincian Pembelian Emas dan Pembiayaan Mulia (diisi oleh Pengelola) (3) Memilih Jangka waktu untuk pengkreditan sesuai dengan yang diinginkan minimal 3 bulan; (4) Membayarkan sejumlah uang muka sedikitnya 20\% sampai $45 \%$ dari nilai emas yang dibeli dan ditentukan berdasarkan berapa lama jangka waktu angsuran yang diambil; (B) Tahap Membuat Bukti Penyerahan Uang Muka, Pengelola menerima formulir beserta uang muka sesuai dengan ketentuan, maka pengelola membuat bukti penyerahan uang muka untuk diberikan kepada nasabah; (C) Tahap Melakukan Akad, Akad dilakukan untuk membuat kesapakatan terhadap pembelian kredit ini sesuai dengan ketentuan dan tidak ada pihak yang merasa dirugikan, form akad tersebut dicantumkan 2 buah materai. Form akad dibuat 2 rangkap, rangkap pertama diberikan kepada pembeli dan rangkap kedua disimpan oleh pengelola untuk arsip; (D) Tahap Pembayaran Pembiayaan Mulia, Pembayaran Pembiayaan dilakukan nasabah secara periodik kepada pengelola sesuai dengan ketentuan yang sudah ditetapkan, (E) Tahap Penyerahan, 
Penyerahan logam mulia/emas dilakuakan pada saat nasabah melunasi pembayaran. Setelah nasabah melakukan pelunasan maka buku kredit dapat ditukar dengan logam mulia yang diorderdan akan menerima Bukti Pembelian; (F) Tahap Penagihan, PT. Pegadaian tidak melakukan penagihan secara periodik, melainkan PT. Pegadaian menunggu nasabah melunasi pembayaran sesuai jangka waktu pengkreditan yang telah dipilih nasabah, apabila jangka waktu telah melewati ketentuan maka emas yang telah di pesan akan dijual kembali.

Sejarah Berdirinya Pegadaian, Pegadaian dimulai pada saat Pemerintahan Belanda (VOC) mendirikan Bank Leening. Yaitu Lembaga Keuangan yang memberikan kredit dengan sistem gadai. Lembaga ini pertama kali didirikan di Batavia pada 20 Agustus 1746. Ketika Inggris mengambil alih kekuasaan Indonesia dari tangan Belanda (1811-1816). Bank Van Leening milik pemerintah dibubarkan dan masyarakat diberi keleluasaan untuk mendirikan usaha pegadaian asal mendapat lisensi dari pemerintah daerah setempat. Namun metode yang dipakai menjalankanpraktek rentenir atau lintah darat. Hal itu dirasakan kurang menguntungkan pemerintah setempat sehingga pendirian pegadaian diberikan kepada pihak umum yang mampu membayarkan pajak yang tinggi kepada pemerintah. Selanjutnya pegadaian milik pemerintah tetap diberi fasilitas monopoli atas kegiatan pegadaian di Indonesia. Dalam perkembangannya 54 pegadaian sudah beberapa kali berubah status, yaitu Perusahaan Negara (PN) sejak 1 Januari 1961, kemudian berdasarkan PP No.10/1990 (yang diperbaharui dengan PP No.103/200) berubah menjadi Perusahaan Umum (PERUM) dan pada tanggal 01 April 2012 berubah menjadi Perseoran Terbatas (PT).

Visi dan Misi Perusahaan, Dalam suatu Perusahaan selalu memiliki pembeda dari pesaingnya, dan juga menjadi motivasi Perusahaan dalam meningkatkan kinerja Perusahaan yakni terdapat visi dan misi Perusahaan, berikut adalah visi dan misi PT. Pegadaian Cabang Sorong,

Visi Perusahaan: Sebagai solusi bisnis terpadu terutama berbasis gadai yang selalu menjadi market leader dan mikro berbasis fidusia selalu menjadi yang terbaik untuk masyarakat menengah kebawah.

Misi Perusahaan: a. Memberikan pembiayaan yang tercepat, termudah, aman dan selalu memberikan pembinaan terhadap usaha golongan menengah kebawah untuk mendorong pertumbuhan ekonomi; b. Memastikan peralatan pelayanan dan infrastruktur yang memberikan kemudahan dan kenyamanan diseluruh pegadaian dalam mempersiapkan diri menjadi pemain regional dan tetap menjadi pilihan utama masyarakat; c. Membantu pemerintah dalam 
meningkatkan kesejahteraan masyarakat golongan menengah kebawah dan melaksanakan usaha lain dalam rangka optimalisasi sumber daya perusahaan.

Budaya Perusahaan, Untuk mendukung terwujudnya visi dan misi perseroan, maka telah ditetapkan budaya perusahaan yang harus selalu dipelajari, dipahami, dihayati, dan dilaksanakan untuk seluruh Insan Pegadaian yaitu jiwa INTAN (Inovatif, Nilai Moral Tinggi, Terampil, Adi Layanan, Nuansa Citra).

Struktur Organisasi Perusahaan, Berikut adalah gambaran umum struktur organisasi pada PT. Pegadaian Cabang Sorong; (a). Pemimpin Cabang, Tugas: mempertanggung jawabkan hasil kerja, Mengontrol cara kerja karyawan, Memberikan izin untuk memperbaiki penjelasan data yang salah; (b). Analisis Kredit, Tugas : Melakukan analisis kelayakan bisnis fidusia sesuai dengan ketentuan yang berlaku.; (c). Kasir, Tugas : Melaksanakan penerimaan pelunasan uang pinjaman dari nasabah sesuai dengan ketentuan yang berlaku. Menerima yang dari penjualan jaminan lelang. Membayar uang pinjaman kredit kepada nasabah sesuai dengan ketentuan yang berlaku. Melakukan pembayaran segala pengeluaran yang terjadi di Kantor Cabang Sorong.; (d). Penaksir Cabang, Tugas : Menerima dan menaksir barang jaminan yang diberikan oleh nasabah.; (e). Customer Service Tugas : menyampaikan informasi kepada nasabah terkait produk-produk pegadaian.; (f). Pengelola UPC, Tugas: Pejabat struktur sebagai pemimpin pada Kantor Unit Pembantu Cabang yang tugasnya bertanggung jawab atas semua aktifitas yang berlangsung pada kantor yang menjadi tanggung jawabnya.; (g) Petugas Keamanan, Tugas: Melaksanakan ketertiban dan keamanan dilingkungan Kantor Pegadaian Cabang Sorong dan UPC serta memberika informasi kepada nasabah sesuai dengan ketentuan. (h) Petugas Gudang, Tugas : Memeriksa secara berkala terhadap keadaan gudang penyimpanan barang jaminan selain barang akantor. Penyimpanan, mengurus gudang barang jaminan emas dengan cara menerima, menyimpan, merawat dan mengeluarkan barang jaminan. Menerima barang-barang jaminan selain barang kantor. Melakukan pengelompokan barang jaminan sesuai dengan rubik dan bulan kredit serta penyusunannya sesuai dengan nomer SBK yang mengatur penyimpanan.

\section{SIMPULAN}

Upaya dalam penyelesaiaan kredit macet dalam pelaksanaan pembiayaan Logam MULIA dengan akad murabahah adalah dengan dua cara yaitu, Lelang Logam Mulia dan Penawaran perpindahan status kredit yaitu Krasida, KCA dan Buyback, Hambatan-Hambatan yang yang terjadi dalam 
proses penyelesaian kredit macet yaitu Hambatan dari nasabah dan Pegadaian, Hambatan Sarana Pendukung dan Hambatan Masyarakat.

\section{DAFTAR PUSTAKA}

Al Albani, As-Syaikh Nashirudin, Silsilah Alhadits Ash-Shohihah, Riyadh : Maktabah al-ma"arif. Antonio, Syafie' I, 2001. Bank Syariah : dari Teori ke Praktik, Jakarta : Gema Insani.

Arthesa, Desi, 2006. Bank dan Lembaga Keuangan Bukan Bank, Jakarta : PT. Indeks Kelompok Gramedia.

Gozali, Ahmad, 2005. Serba Serbi Kredit Syariah : Jangan Ada Bunga diantara Kita, Jakarta : PT. Elex Media Koputindo.

Lathief, AH Azharuddin, 2005. Fiqh Muamalah, Jakarta : UIN Jakarta Press.

Mardani, 2012. Fiqh Ekonomi Syariah : Fiqh Muamalah,, Jakarta : Kencana Prenada Media Group.

Muslehuddin, Muhammad, 2004. Sistem Perbankan dalam Islam, Jakarta : PT. Rineka Cipta.

Nasrun, Harun, 2007. Fiqh Muamalah, Jakarta : Gaya Media Pratama.

Pusat Pembinaan dan Pengembangan Bahasa, 2002. Kamus Besar Bahasa Indonesia, Jakarta : Balai Pustaka.

Rahman Ghazaly, Abdul, 2010. Fiqh Muamalah,Kencana Prenada Media Group.

Rachman F, Maya F, 2013. Manajemen Perkreditan Bank Umum : Teori Masalah Kebijakan dan Aplikasinya, Bandung: Alfabeta.

Suhendi, Hendi, 2004. Fiqh Muamalah, Jakarta : PT. Raja Grafindo Persada.

Widjaja, Gunawan, Kartini Muljadi, 2004. Jual Beli, Jakarta : PT. Raja Grafindo Persada. 